\title{
Seroprevalence of Herpes simplex virus types 1 and 2 in Indian and Filipino migrant populations in Qatar: a cross-sectional survey
}

Gheyath Nasrallah,, ${ }^{1,2}$ Soha Dargham, ${ }^{3}$ Manale Harfouche ${ }^{3}$ and Laith Abu-Raddad ${ }^{3,4}$

${ }^{1}$ Department of Biomedical Science, College of Health Sciences, Qatar University, Doha, Qatar. ${ }^{2}$ BioMedical Research Center, Qatar University, Doha, Qatar. ${ }^{3}$ Infectious Disease Epidemiology Group, Weill Cornell Medicine-Qatar, Cornell University, Qatar Foundation - Education City, Doha, Qatar. ${ }^{4}$ Department of Healthcare Policy and Research, Weill Cornell Medicine, Cornell University, New York, United States of America. (Correspondence to Laith J. Abu-Raddad: Lja2002@qatar-med.cornell.edu).

\begin{abstract}
Background: The epidemiology of herpes simplex virus infections is of growing interest but information on its seroprevalence in many countries is scarce.

Aims: This study aimed to measure the seroprevalence of herpes simplex virus type 1 and type 2 in Filipino and Indian men living in Qatar.

Methods: Blood serum specimens were collected from male blood donors aged $\geq 18$ years in Qatar from 2013 to 2016 . HerpeSelect $^{\circledR} 1 / 2$ and Euroline-WB assays were used to measure antibodies to herpes simplex virus types 1 and 2 in 120 Filipino and 325 Indian men.

Results: The seroprevalence of herpes simplex virus-1 was 84.9\% (95\% confidence interval (CI): $78.4-90.0 \%)$ in Filipino men and 48.3\% (95\% CI: 43.6-53.0\%) in Indian men. The seroprevalence of herpes simplex virus-2 was 8.3\% (95\% CI: 4.6-13.7\%) in Filipinos and 3.7\% (95\% CI: 2.2-5.9\%) in Indians. The seroprevalence of herpes simplex virus types 1 and 2 increased with age, but this trend was only statistically significant in Indian men $(P=0.013$ and $P=0.011$ respectively).

Conclusions: The seroprevalence rates of herpes simplex virus-2 in Filipino and Indian men living in Qatar were similar to those found in the Philippines and India. However, the seroprevalence of herpes simplex virus-1 in Indians, while similar to that found in India, was substantially lower than that of other countries in Asia and developing countries worldwide, which needs further investigation.

Keywords: herpes virus 1, herpes virus 2, herpes simplex, seroprevalence, seroepidemiological studies, Philippines, India, Qatar

Citation: Nasrallah G; Dargham S; Harfouche M; Abu-Raddad L. Seroprevalence of herpes simplex virus types 1 and 2 in Indian and Filipino migrant populations in Qatar: a cross-sectional survey. East Mediterr Health J. 2020;26(5):609-615. https://doi.org/10.26719/2020.26.5.609

Received: 23/04/18; accepted: 18/09/18

Copyright (C) World Health Organization (WHO) 2019. Open Access. Some rights reserved. This work is available under the CC BY-NC-SA 3.0 IGO license https://creativecommons.org/licenses/by-nc-sa/3.o/igo
\end{abstract}

\section{Introduction}

Herpes simplex virus type 1 (HSV-1) and type 2 (HSV-2) are widespread lifelong infections (1-4), and are associated with mild to severe health consequences. Symptoms of HSV-1 infection include oral and facial lesions and the infection can affect the central nervous system, leading to oral, ocular, cutaneous and neural clinical manifestations such as herpes labialis (cold sores), herpetic whitlow, gingivostomatitis, neonatal herpes, blindness, meningitis and encephalitis $(5,6)$. HSV-2 infection is one of the leading causes, if not the leading cause, of genital herpes and genital ulcer disease worldwide $(3,4,7,8)$.

HSV-1 is generally acquired through the oral route during childhood with mild to serious morbidity, but evidence from the United States of America (USA) and Western Europe indicates a growing sexual acquisition through oral sex $(5,9,10)$. HSV-2 is nearly always acquired sexually and is strongly associated with HIV infection (11-13), with its prevalence patterns providing key inferences about the structure of sexual networks (14). Evidence suggests also an association between HSV-1 and HSV-2 infections $(15,16)$.
The epidemiology of HSV infections is of growing interest - the World Health Organization is leading the development of a business case for HSV vaccines to tackle this infection and disease burden (17). This effort, however, is challenged by the limited information on the current antibody prevalence (that is, seroprevalence) as well as inadequate knowledge of the epidemiology of both HSV infections in many countries (17).

We recently provided measures of HSV-1 seroprevalence (18) and HSV-2 seroprevalence (19) in 10 national Middle Eastern and North African populations currently living in Qatar, including Qatari citizens. One of the findings was an unexpectedly low seroprevalence of HSV-1 in Pakistanis, suggesting that HSV-1 seroprevalence in populations from the Indian subcontinent could be lower than global levels; the reasons for this low seroprevalence are still not known. Existing data on HSV-1 seroprevalence in Indian populations seem to support this conjecture (20-22).

Against this background, and with the availability of blood donor serum specimens from the Indian migrant population in Qatar, where Indian expatriates constitute nearly 25\% of Qatar's current resident population (23), we aimed to measure the seroprevalence of HSV-1 and 
HSV-2 in an Indian population and compare them to other migrant populations in Qatar and Indians in India. In addition, as data on HSV-1 seroprevalence in Filipino populations are lacking (21) and Filipino people are the third largest group of migrants in Qatar (23), we aimed to measure HSV-1 seroprevalence in a Filipino migrant population using the blood donor serum specimens available. Stressing the importance of migrant health, the limitations in global HSV-2 seroprevalence data $(3,4)$ and the availability of serum specimens, we further aimed to measure HSV-2 seroprevalence in these two populations. Lastly, we aimed to generate inferences about the similarities and differences in the seroprevalence of HSV-1 and HSV-2 in different countries and populations in order to deepen our understanding of the global epidemiology of these two infections.

\section{Methods}

\section{Study samples}

The study samples consisted of Filipino and Indian male blood donors who donated blood between June 2013 and June 2016 at Hamad Medical Corporation, the largest provider of health care in Qatar. The blood specimens were collected - originally for other studies (24-27) - from 120 Filipino and 620 Indian male adults aged $\geq 18$ years.

We stratified the Filipino sample into three age groups: $\leq 34,35-44$ and $\geq 45$ years. However, we categorized the larger Indian sample into seven 5-year age groups: $\leq 24,25-29,30-34,35-39,40-44,45-49$ and $\geq 50$ years. We chose these age groups to optimize the assessment of the age-specific seroprevalence of HSV-1 and HSV-2, given the number of specimens available for each nationality.

For the Filipino sample, we tested all 120 specimens. For the Indian sample, we used a sample size of 50 specimens per age group for the analysis. This number was calculated based on a significance level of $5 \%$ and an HSV-1 seroprevalence for each age group of $88 \%$ with a $10 \%$ precision level, and an HSV-2 seroprevalence for each age group of $2 \%$ with a $4 \%$ precision level. We based the two seroprevalence figures used for the sample size calculations on previous studies conducted in different national populations living in Qatar $(18,19)$, as well as global data $(3,4,12,21)$. However, as there are limited to no data on HSV types 1 and 2 in Filipino and Indian populations, we set a higher precision level. We finally used 325 specimens for HSV serology testing for the Indian sample. For each of the age groups of 25-29, 30-34, $35-39,40-44$, and 45-49 years, we randomly selected 50 specimens from the available specimens using a random number generator. For the remaining age groups $(\leq 24$ and $\geq 50$ years), we tested all available specimens ( $n=40$ and $\mathrm{n}=35$, respectively).

\section{Specimen testing}

Laboratory analysis methods have been described previously $(18,19,28,29)$. Briefly, for HSV-1 serology testing, we used the HerpeSelect ${ }^{\circledR} 1$ enzyme linked immunosorbent assay (ELISA) kit (Cat. No. EL0910G-5, Focus Diagnostics, USA). In light of known limitations of false positives for HSV-2 antibody in ELISA tests, we used a twotest algorithm to identify specimens positive for HSV-2 based on previous work (19). We first used the HerpeSelect ${ }^{\circledR} 2$ ELISA kit (Cat. No. ELo910G-5, Focus Diagnostics, USA) to screen the sera. We then used the Euroline-WB assay (Cat. No. DY 2531-2401-1 G, Euroimmun Laboratory, Germany) to test all the positive and equivocal sera to confirm positivity. We followed manufacturers' instructions for interpretation of each assay.

\section{Statistical analysis}

We estimated the overall and age-specific seroprevalence of HSV-1 and HSV-2 and 95\% confidence intervals (CI). We examined trends in seroprevalence by age using the Cochran-Armitage test. We set the significance level at $5 \%$ and used SPSS, version 24 for all analyses.

\section{Ethical considerations}

The ethic boards of Hamad Medical Corporation, Qatar University and Weill Cornell Medicine-Qatar approved the use of the anonymized specimens.

\section{Results}

\section{Filipino sample}

The median age of the Filipino sample was 37 years. Of the 120 serum specimens tested for antibodies to HSV-1 and HSV-2, 101 sera tested positive for HSV-1, 18 sera tested negative and one was equivocal, giving an HSV-1 seroprevalence of $84.9 \%$ (95\% CI: 78.4-90.0\%). HSV-1 seroprevalence increased with age, from 84.6\% (95\% CI: 74.0-92.1\%) in those aged $\leq 34$ years to $88.9 \%$ (95\% CI: 73.7-96.9\%) in those aged $\geq 45$ years, but this trend was not statistically significant $(P$-value for trend $=0.693$; Figure $1 \mathrm{~A})$.

HSV-2 testing using HerpeSelect ${ }^{\circledR} 2$ ELISA identified 10 sera as positive, 109 as negative and one as equivocal. Confirmatory testing was done on 11 specimens, and 10 were confirmed as positive and one as negative, giving an HSV-2 seroprevalence of $8.3 \%$ (95\% CI: 4.6-13.7\%). HSV-2 seroprevalence increased with age, from 5.8\% (95\% CI: 1.6$14.2 \%$ ) in those aged $\leq 34$ years to $10.7 \%$ (95\% CI: $3.025 .4 \%$ ) in those aged $\geq 45$ years, but this trend was not statistically significant $(P$-value for trend $=0.406$; Figure $1 \mathrm{~B})$.

\section{Indian sample}

The median age of the Indian sample was also 37 years. Of the 325 serum specimens tested for HSV-1 and HSV-2 antibodies, 156 sera were positive for HSV-1, 167 were negative and two were equivocal, giving an HSV-1 seroprevalence of $48.3 \%$ (95\% CI: 43.6-53.0\%). HSV-1 seroprevalence increased with age, from $40.0 \%$ (95\% CI: $26.9-54.2 \%$ ) in those aged $\leq 24$ years to $62.9 \%$ (95\% CI: $47.6-76.4 \%$ ) in those aged $\geq 50$ years, a statistically significant trend $(P$-value for trend $=0.013$; Figure $2 \mathrm{~A})$.

HSV-2 testing using HerpeSelect ${ }^{\circledR} 2$ ELISA identified 20 sera as positive and 305 as negative. Confirmatory 
Figure 1 Overall and age-specific seroprevalence of $A$ ) herpes simplex virus type 1 and $B$ ) herpes simplex virus type 2 in male Filipino blood donors living in Qatar
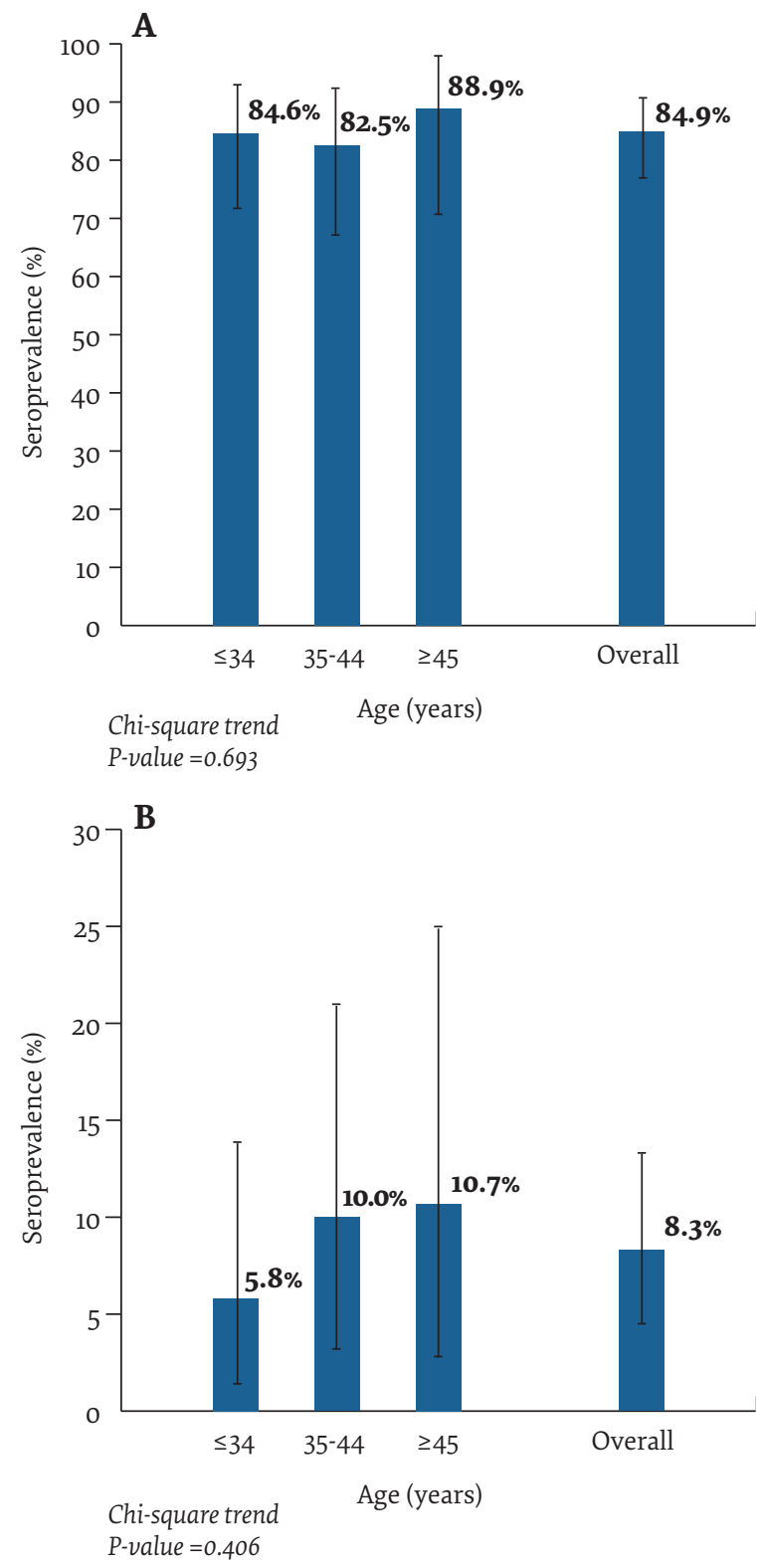

testing was done on 20 specimens, and 12 were confirmed as positive, seven as negative and one as equivocal, giving an HSV-2 seroprevalence of 3.7\% (95\% CI: $2.2-5.9 \%$ ). HSV2 seroprevalence increased with age, from 0.0\% (95\% CI: $0.0-7.2 \%$ ) in those aged $\leq 24$ years to $8.6 \%$ (95\% CI: $2.4^{-}$ $20.7 \%$ ) in those aged $\geq 50$ years, a statistically significant trend $(P$-value for trend $=0.011$; Figure $2 \mathrm{~B})$.

\section{Discussion}

Against a background of limited global data and using quality assays, we estimated the overall and age-specific seroprevalence of HSV-1 and HSV-2 in Filipino and Indian male migrant populations in Qatar. Of the Filipino sample, $85 \%$ were HSV-1 seropositive and < $10 \%$ were
HSV-2 seropositive. Of the Indian sample, only 48\% were HSV-1 seropositive and $<10 \%$ were HSV-2 seropositive. The seroprevalence of HSV-1 and HSV-2 in both samples showed increasing trend with age which reflects the higher cumulative exposure risk with age, as expected based on global data (3). However, this trend was not statistically significant for Filipino men.

To the best of our knowledge, this is the first time that HSV-1 seroprevalence has been reported in the literature for a Filipino population. HSV-1 seroprevalence in Filipinos was similar to that in other resident populations in Qatar (18) and to Asian populations in general (21). Of note, HSV-1 seroprevalence in Indians was much lower than that in other resident populations in Qatar $(48 \%$ versus $>80 \%$ ) (18), and in developing countries globally (> $80 \%)(3,21,30-32)$. However, it was similar to that reported in other studies on Indians, which was about 50\% (20-22), which represents the home country rather than current residence, which can be explained because they had only recently migrated to Qatar.

Our findings highlight an apparent unexplained anomaly in global HSV-1 seroprevalence data: low seroprevalence in the Indian subcontinent compared with what is expected for developing countries $(3,18,21,30-$ 32). These findings also suggest that about $50 \%$ of Indians may start their sexual activity lacking protective antibodies against HSV-1, and are thus potentially at risk of genital acquisition of HSV-1, which could lead to genital herpes.

HSV-2 seroprevalence in both our Filipino and Indian samples was consistent with that found in the Philippines (33) and in India (34-37), and comparable to that found in other resident populations in Qatar (19) as well as in Asia in general $(3,4)$. This finding probably suggests lower levels of sexual risk behaviour $(14,38,39)$, reflecting more conservative attitudes towards sexuality in these areas.

Our study has some limitations. The sample consisted of male blood donors and is not necessarily representative of women nor of the Filipino or Indian population at large, in each country. Blood donors are a healthy population with possibly lower levels of HSV infections. Only a few sociodemographic attributes were gathered, limiting the potential to assess associations with infection status. Although we used high-quality and validated commercial assays, existing data suggest potential population variation in assay sensitivity and specificity (40), which may affect the estimated seroprevalence.

In conclusion, this study fills a gap in the global map of HSV seroprevalence data. About $85 \%$ and $<10 \%$ of the Filipino migrant population in Qatar were HSV-1 and HSV-2 seropositive, respectively, while only about $50 \%$ and $<10 \%$ of the Indian migrant population were HSV-1 and HSV-2 seropositive, respectively. While HSV-1 levels in Filipinos followed global patterns, those in Indians affirm and demonstrate an anomaly of unexplained low HSV-1 seroprevalence in Indian subcontinent populations. 
Figure 2 Overall and age-specific seroprevalence of A) herpes simplex virus type 1 and B) herpes simplex virus type 2 in male Indian blood donors living in Qatar
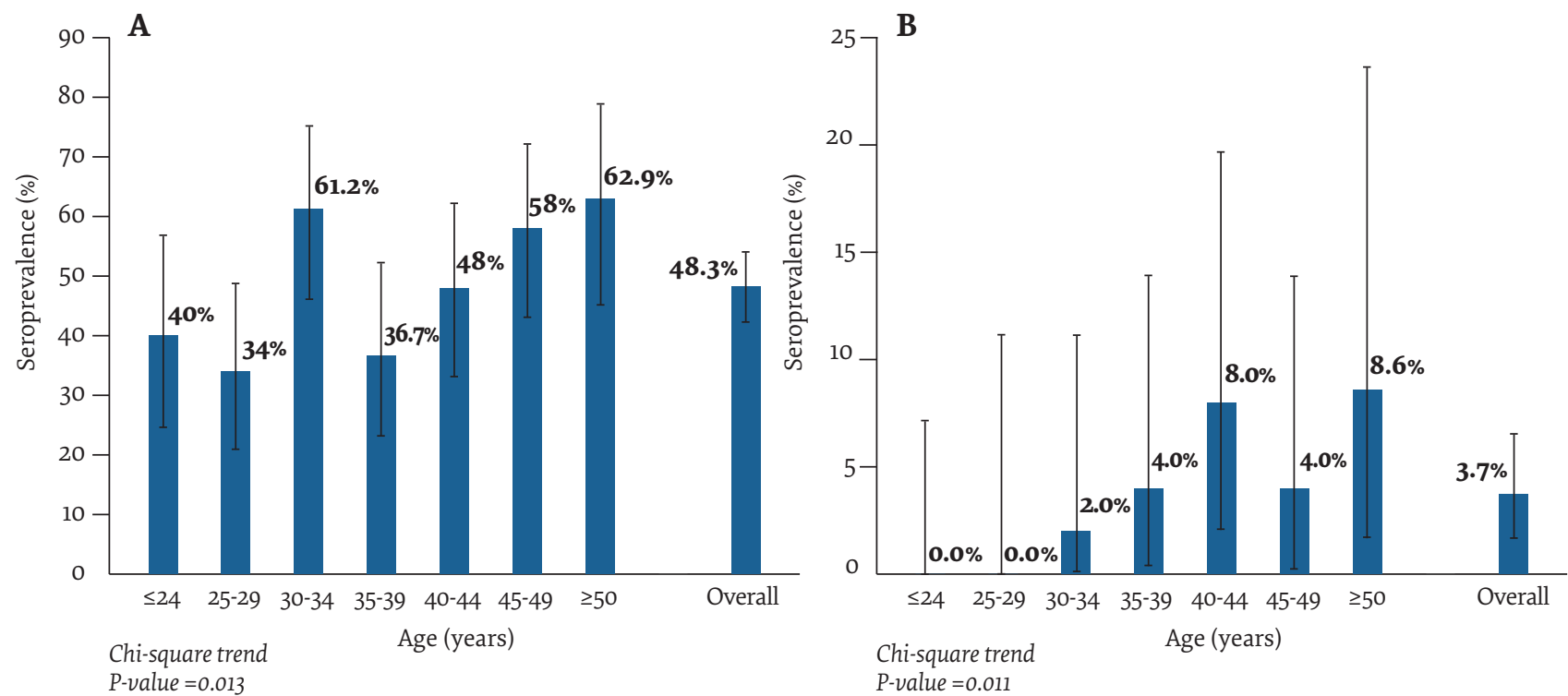

\section{Acknowledgements}

We thank Ms. Adona Canlas at Weill Cornell Medicine-Qatar for her administrative support, and Ms Enas Al-Absi, Ms Rana Al-Disi, Ms Malaz Comi, Ms Malaz Elsidiq, Ms Sana Khan, Ms Layla Mohammed, Ms Mariam Nofal, and Ms Afifah Sahara at Qatar University for their support in HSV testing. We also thank Dr Asmaa Al-Marwani, Ms Maria Samatti and Ms Sana Abohasera for blood specimen collection, and the Biostatistics, Epidemiology, and Biomathematics Research Core at Weill Cornell Medicine-Qatar.

Funding: Testing kits were provided through pilot funding by the Biomedical Research Programme at Weill Cornell Medicine-Qatar. GKN acknowledges support from Qatar university internal grant, No. QUST-CHS-SPR-15/16-7 and from the Qatar National Research Fund UREP, grant number UREP18-001-3-001. LJA, SRD and MH acknowledge support from the Qatar National Research Fund (a member of Qatar Foundation) for study conception and design through NPRP grant number 9-040-3-008. The findings reported herein are solely the responsibility of the authors.

Competing interests: None declared.

\section{Séroprévalence du virus de l'herpès de types 1 et 2 parmi les populations migrantes indiennes et philippines au Qatar : enquête transversale}

\section{Résumé}

Contexte : L'épidémiologie des infections par le virus de l'herpès suscite un intérêt croissant, mais les informations relatives à sa séroprévalence dans de nombreux pays sont rares.

Objectifs : La présente étude visait à mesurer la séroprévalence du virus de l'herpès de types 1 et 2 parmi les hommes philippins et indiens vivant au Qatar.

Méthodes : Des échantillons de sérum sanguin ont été prélevés sur des donneurs de sang masculins âgés d'au moins dix-huit ans au Qatar entre 2013 et 2016. Les tests HerpeSelect ${ }^{\circledR} 1 / 2$ et Euroline-WB ont été utilisés pour mesurer les anticorps dirigés contre le virus de l'herpès de types 1 et 2 chez 120 hommes philippins et 325 hommes indiens.

Résultats : La séroprévalence du virus de l'herpès de type 1 était de 84,9\% (intervalle de confiance (IC) à 95 \%: 78,4 - 90,0 \%) chez les hommes philippins et de 48,3\% (IC à $95 \%$ : 43,6 - 53,0\%) chez les hommes indiens. La séroprévalence du virus de l'herpès de type 2 était de 8,3\% (IC à $95 \%$ : 4,6 - 13,7\%) chez les hommes philippins et de 3,7 \% (IC à 95 \% : 2,2 - 5,9\%) chez les hommes indiens. La séroprévalence du virus de l'herpès de types 1 et 2 augmentait avec l'âge, mais cette tendance n'était statistiquement importante que chez les homme indiens ( $p=0,013$ et $p=0,011$ respectivement).

Conclusions : Les taux de séroprévalence du virus de l'herpès de type 2 parmi les hommes philippins et indiens vivant au Qatar étaient similaires à ceux constatés aux Philippines et en Inde. Toutefois, le taux de séroprévalence du virus de l'herpès de type 1 chez les Indiens, bien que comparable à celui relevé en Inde, était beaucoup moins élevé que celui des autres pays d'Asie et des pays en développement, ce qui mérite d'être étudié plus attentivement. 
الانتشار المصلي لفيروس المربس البسيط (النمط 1 والنمط 2) في أوساط المجموعات السكانية المندية والفلبينية

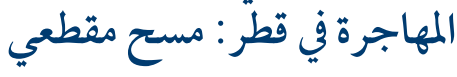
غياث نصر الله، سهى درغام، منال حرفوش، ليث أبو رداد

الخلفية: يتزايد الاهتمام بدراسة السمات الوبائية لحالات العدوى بفيروس الهربس البسيط، غير أن المعلومات حول انتشاره مصليا في العديد من البُلدان شحيحة للغاية.

الأهداف: هدفت هذه الدر اسة إلى قياس الانتشار المصلي لفيروس الهربس البسيط (النمط 1 و النمط 2) بين الرجال الذين يعيشون في قطر ويتمون

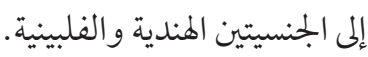

طرق البحث: أخذت عينات من مصل الدم من متبرعين بالدم من الذكور يبلغون من العمر 18 عاما أو أكثر في قطر في الفترة من 2013 و وحتى

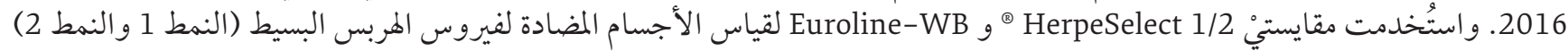

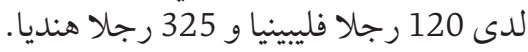

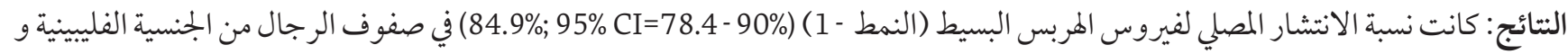
(48.3\%; 95\% CI=43.6-53.0\%)

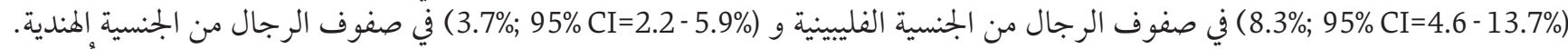

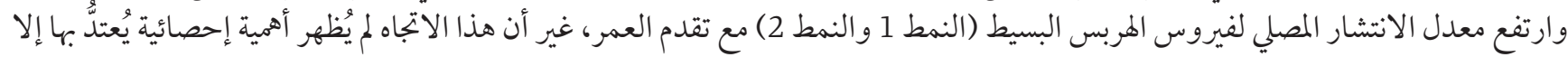

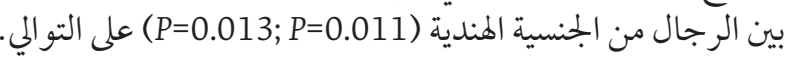

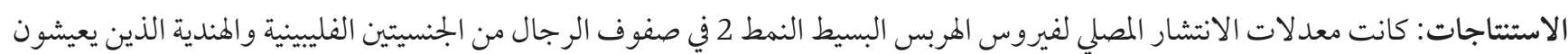

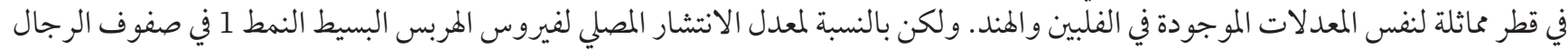

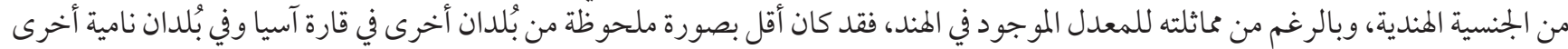

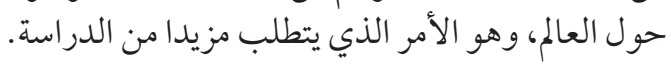

\section{References}

1. Looker KJ, Magaret AS, Turner KM, Vickerman P, Gottlieb SL, Newman LM. Global estimates of prevalent and incident herpes simplex virus type 2 infections in 2012. PLoS One. 2015;10(1):e114989. https://doi.org/10.1371/journal.pone.0114989

2. Looker KJ, Magaret AS, May MT, Turner KM, Vickerman P, Gottlieb SL, et al. Global and regional estimates of prevalent and incident herpes simplex virus type 1 infections in 2012. PLoS One. 2015;10(10):e0140765. https://doi.org/10.1371/journal.pone.0140765

3. Smith JS, Robinson NJ. Age-specific prevalence of infection with herpes simplex virus types 2 and 1: a global review. J Infect Dis. 2002;186(Suppl 1):S3-28. https://doi.org/10.1086/343739

4. Weiss H. Epidemiology of herpes simplex virus type 2 infection in the developing world. Herpes. 2004;11(Suppl 1):24A-35A

5. Bernstein DI, Bellamy AR, Hook EW, 3rd, Levin MJ, Wald A, Ewell MG, et al. Epidemiology, clinical presentation, and antibody response to primary infection with herpes simplex virus type 1 and type 2 in young women. Clin Infect Dis. 2013;56(3):344-51. https://doi.org/10.1093/cid/cis891

6. Brady RC, Bernstein DI. Treatment of herpes simplex virus infections. Antiviral Res. 2004;61(2):73-81. https://doi.org/10.1016/j. antiviral.2003.09.006

7. Holmes KK. Sexually transmitted diseases. 4th ed. New York: McGraw-Hill Medical; 2008:2166.

8. Morse SA. Etiology of genital ulcer disease and its relationship to HIV infection. Sex Transm Dis. 1999;26(1):63-5. https://doi. org/10.1097/00007435-199901000-00010.

9. Ayoub HH, Chemaitelly H, Abu-Raddad LJ. Characterizing the transitioning epidemiology of herpes simplex virus type 1 in the USA: model-based predictions. BMC Med. 2019;17(1):57. https://doi.org/10.1186/s12916-019-1285-x

10. Chemaitelly H, Nagelkerke N, Omori R, Abu-Raddad LJ. Characterizing herpes simplex virus type 1 and type 2 seroprevalence declines and epidemiological association in the United States. PLoS One. 2019;14(6):e0214151. https://doi.org/10.1371/journal. pone.0214151

11. Abu-Raddad LJ, Magaret AS, Celum C, Wald A, Longini IM, Jr., Self SG, et al. Genital herpes has played a more important role than any other sexually transmitted infection in driving HIV prevalence in Africa. PLoS One. 2008;3(5):e2230. https://doi. org/10.1371/journal.pone.0002230 
12. Kouyoumjian SP, Heijnen M, Chaabna K, Mumtaz GR, Omori R, Vickerman P, et al. Global population-level association between herpes simplex virus 2 prevalence and HIV prevalence. AIDS. 2018;32(10):1343-52. https://doi.org/10.1097/ QAD.0000000000001828

13. Omori R, Nagelkerke N, Abu-Raddad LJ. HIV and herpes simplex virus type 2 epidemiological synergy: misguided observational evidence? A modelling study. Sex Transm Infect. 2018;94(5):372-6. https://doi.org/10.1136/sextrans-2017-053336

14. Omori R, Abu-Raddad LJ. Sexual network drivers of HIV and herpes simplex virus type 2 transmission. AIDS. 2017;31(12):1721-32. https://doi.org/10.1097/QAD.0000000000001542

15. Looker KJ, Garnett GP. A systematic review of the epidemiology and interaction of herpes simplex virus types 1 and 2. Sex Transm Infect. 2005;81(2):103-7. https://doi.org/10.1136/sti.2004.012039

16. Nasrallah GK, Dargham SR, Abu-Raddad LJ. Negative epidemiological association between HSV-1 and HSV-2 infections. Heliyon. 2019;5(10):e02549. https://doi.org/10.1016/j.heliyon.2019.e02549

17. Gottlieb SL, Giersing B, Boily MC, Chesson H, Looker KJ, Schiffer J, et al. Modelling efforts needed to advance herpes simplex virus (HSV) vaccine development: key findings from the World Health Organization Consultation on HSV Vaccine Impact Modelling. Vaccine. 2019;37(50):7336-45. https://doi.org/10.1016/j.vaccine.2017.03.074

18. Nasrallah GK, Dargham SR, Mohammed LI, Abu-Raddad LJ. Estimating seroprevalence of herpes simplex virus type 1 among different Middle East and North African male populations residing in Qatar. J Med Virol. 2018;90(1):184-90. https://doi.org/10.1002/ jmv.24916

19. Dargham SR, Nasrallah GK, Al-Absi ES, Mohammed LI, Al-Disi RS, Nofal MY, et al. Herpes simplex virus type 2 seroprevalence among different national populations of Middle East and North African men. Sex Transm Dis. 2018;45(7):482-7. https://doi. org/10.1097/OLQ.0000000000000791

20. Kaur R, Gupta N, Baveja UK. Seroprevalence of HSV1 and HSV2 infections in family planning clinic attenders. J Commun Dis. 2005;37(4):307-9

21. Khadr L, Harfouche M, Omori R, Schwarzer G, Chemaitelly H, Abu-Raddad LJ. The epidemiology of herpes simplex virus type 1 in Asia: systematic review, meta-analyses, and meta-regressions. Clin Infect Dis. 2019;68(5):757-72. https://doi.org/10.1093/cid/ ciy562

22. Patwardhan V, Bhalla P. Role of type-specific herpes simplex virus-1 and 2 serology as a diagnostic modality in patients with clinically suspected genital herpes: a comparative study in Indian population from a tertiary care hospital. Indian J Pathol Microbiol. 2016;59(3):318-21. https://doi.org/10.4103/0377-4929.188104

23. Qatar Population. World Population Review; 2017 (http://worldpopulationreview.com/countries/qatar-population/, accessed 7 December 2017).

24. AbuOdeh R, Al-Mawlawi N, Al-Qahtani AA, Bohol MF, Al-Ahdal MN, Hasan HA, et al. Detection and genotyping of torque teno virus (TTV) in healthy blood donors and patients infected with HBV or HCV in Qatar. J Med Virol. 2015;87(7):1184-91. https://doi. org/10.1002/jmv.24146

25. AbuOdeh RO, Al-Absi E, Ali NH, Khalili M, Al-Mawlawi N, Hadwan TA, et al. Detection and phylogenetic analysis of human pegivirus (GBV-C) among blood donors and patients infected with hepatitis B virus (HBV) in Qatar. J Med Virol. 2015;87(12):2074-81. https://doi.org/10.1002/jmv.24289

26. Al-Qahtani AA, Alabsi ES, AbuOdeh R, Thalib L, El Zowalaty ME, Nasrallah GK. Prevalence of anelloviruses (TTV, TTMDV, and TTMV) in healthy blood donors and in patients infected with HBV or HCV in Qatar. Virol J. 2016;13(1):208. https://doi.org/10.1186/ s12985-016-0664-6

27. Nasrallah GK, Al Absi ES, Ghandour R, Ali NH, Taleb S, Hedaya L, et al. Seroprevalence of hepatitis E virus among blood donors in Qatar (2013-2016). Transfusion. 2017;57(7):1801-7. https://doi.org/10.1111/trf.14116

28. Nasrallah GK, Dargham SR, Sahara AS, Elsidiq MS, Abu-Raddad LJ. Performance of four diagnostic assays for detecting herpes simplex virus type 2 antibodies in the Middle East and North Africa. J Clin Virol. 2019;111:33-8. https://doi.org/10.1016/j. jcv.2019.01.001

29. Aldisi RS, Elsidiq MS, Dargham SR, Sahara AS, Al-Absi ES, Nofal MY, et al. Performance evaluation of four type-specific commercial assays for detection of herpes simplex virus type 1 antibodies in a Middle East and North Africa population. J Clin Virol. 2018;103:1-7. https://doi.org/10.1016/j.jcv.2018.03.011

30. Chaabane S, Harfouche M, Chemaitelly H, Schwarzer G, Abu-Raddad LJ. Herpes simplex virus type 1 epidemiology in the Middle East and North Africa: systematic review, meta-analyses, and meta-regressions. Sci Rep. 2019;9(1):1136. https://doi.org/10.1038/ S41598-018-37833-8

31. Harfouche M, Chemaitelly H, Abu-Raddad LJ. Herpes simplex virus type 1 epidemiology in Africa: systematic review, meta-analyses, and meta-regressions. J Infect. 2019;79(4):289-99. https://doi.org/10.1016/j.jinf.2019.07.012

32. Sukik L, Alyafei M, Harfouche M, Abu-Raddad LJ. Herpes simplex virus type 1 epidemiology in Latin America and the Caribbean: systematic review and meta-analytics. PLoS One. 2019;14(4):e0215487. https://doi.org/10.1371/journal.pone.0215487

33. Smith JS, Herrero R, Munoz N, Eluf-Neto J, Ngelangel C, Bosch FX, et al. Prevalence and risk factors for herpes simplex virus type 2 infection among middle-age women in Brazil and the Philippines. Sex Transm Dis. 2001;28(4):187-94. https://doi. org/10.1097/00007435-200104000-00001 
34. Celentano DD, Mayer KH, Pequegnat W, Abdala N, Green AM, Handsfield HH, et al. Prevalence of sexually transmitted diseases and risk behaviors from the NIMH Collaborative HIV/STD Prevention Trial. Int J Sex Health. 2010;22(4):272-84. https://doi.org/1 $0.1080 / 19317611.2010 .494092$

35. Go VF, Solomon S, Srikrishnan AK, Sivaram S, Johnson SC, Sripaipan T, et al. HIV rates and risk behaviors are low in the general population of men in Southern India but high in alcohol venues: results from 2 probability surveys. J Acquir Immune Defic Syndr. 2007;46(4):491-7. https://doi.org/10.1097/qai.obo13e3181594c75

36. Hochberg CH, Schneider JA, Dandona R, Lakshmi V, Kumar GA, Sudha T, et al. Population and dyadic-based seroincidence of herpes simplex virus-2 and syphilis in southern India. Sex Transm Infect. 2015;91(5):375-82. https://doi.org/10.1136/sextrans-2014-051708

37. Panchanadeswaran S, Johnson SC, Mayer KH, Srikrishnan AK, Sivaran S, Zelaya CE, et al. Gender differences in the prevalence of sexually transmitted infections and genital symptoms in an urban setting in southern India. Sex Transm Infect. 2006;82(6):491-5. https://doi.org/10.1136/sti.2006.020768

38. Abu-Raddad LJ, Akala FA, Semini I, Riedner G, Wilson D, Tawil O. Characterizing the HIV/AIDS epidemic in the Middle East and North Africa: time for strategic action. Middle East and North Africa HIV/AIDS Epidemiology Synthesis Project. World Bank/ UNAIDS/WHO Publication. Washington (DC): The World Bank Press; 2010. https://doi.org/10.1596/978-0-8213-8137-3

39. Abu-Raddad LJ, Schiffer JT, Ashley R, Mumtaz G, Alsallaq RA, Akala FA, et al. HSV-2 serology can be predictive of HIV epidemic potential and hidden sexual risk behavior in the Middle East and North Africa. Epidemics. 2010;2(4):173-82. https://doi. org/10.1016/j.epidem.2010.08.003

40. Ashley-Morrow R, Nollkamper J, Robinson NJ, Bishop N, Smith J. Performance of focus ELISA tests for herpes simplex virus type 1 (HSV-1) and HSV-2 antibodies among women in ten diverse geographical locations. Clin Microbiol Infect. 2004;10(6):530-6. https://doi.org/10.1111/j.1469-0691.2004.00836.x 